From imperfect strangers to new citizens: Screening race and ethnicity in Nordic film history

Kate Moffat, University of Stirling

26 Munro Gate, Cornton Road, Bridge of Allan, Stirling, FK9 4DJ, 07812344291, k.1.moffat@stir.ac.uk

\begin{abstract}
Minority politics has become a twenty-first-century global crisis. Nowhere is this more evident than in the five Nordic nations. Looking at representations of race and ethnicity across Nordic film history, I explore how cinema has reflected and subverted ethnic stereotypes against the backdrop of shifting political and economic landscapes.

\section{Contributor details}

Kate Moffat is a PhD student based at the University of Stirling where her research focuses on minority politics in contemporary Nordic film cultures.

\title{
Keywords
}

Nordic cinemas

immigration cinema

race

ethnic identity

Otherness

multiculturalism

Accepted for publication in Journal of Scandinavian Cinema published by Intellect. 
Race and ethnic identity are contested issues in the contemporary Nordic region. The Syrian refugee crisis in 2015 has led to a surge in asylum applications across Europe and has met with both acceptance and hostility. Simultaneously, many European nations are facing their own crises with rising unemployment, welfare austerity and fragmenting national identities (Loftsdóttir and Jensen 2014: 1-2). In these unstable economic and political times, newcomers, particularly those from outside Europe, have provoked suspicion and alarm. The populist far-right have mobilized against immigration and redefined complex economic and political struggles as a fight for traditional values (Wodak 2015: 26-27). In the Nordic countries, the Danish People's Party, Norway's Progress Party, the Sweden Democrats and the True Finns have all risen to prominence with their signature anti-immigrant nationalism.

As both an art form designed to cross cultural and political boundaries and a mainstream method of mass communication, cinema is one of the most effective ways to reflect, confront and challenge the kind of identity politics outlined above. The five Nordic film industries have developed separately and at different stages throughout the twentieth century. As a result, it is not possible to generalize or make sweeping statements about the evolution of a 'Nordic' film culture. However, as this short piece will demonstrate, the respective film industries have always played a role in depicting ethnic and racial stereotypes, and in a wide variety of genres. Following Isolina Ballesteros, who defines immigration cinema as a 'thematic, wide ranging category' (2015:14), I contextualize on-screen representations of race and ethnicity within the complex political landscapes of the Nordic countries and consider how examples from each nation reflect and subvert dominant political and economic narratives.

\section{Framing race and ethnic identities in the emerging Nordic welfare states}

Immigration into and within the Nordic countries has occurred unevenly and at different points in history (Horsti 2008: 277). Although I focus on characters and filmmakers whose backgrounds are non-Nordic, I also account for the treatment of ethnic minorities like the indigenous Sami people and the Nordic countries' small Jewish and Roma populations, especially as these groups have historically always been marked at Other (Wright 1998). Onscreen images of race and ethnicity began during the silent era. For instance, a fascination with 'exotic' gypsies is evident in the Finnish Mustat silmät/'Dark Eyes' and Mustalaishurmaaja/'The Gypsy Charmer', both directed by Valentin Vaala and released in 1929. In Sweden during the 1920s, a number of films reflected the racism and anti-Semitism that was ingrained in the political and cultural mainstream (Gustafsson 2014:152). 
The 1930s gave rise to the Nordic welfare states, where collectivism, egalitarianism and political consensus played a key role in societal development (Kananen 2014: 89). Although these changes developed separately in each Nordic nation, arriving much later in Finland and Norway (Kananen 2014), the concept of the Nordic welfare state has, from its inception, had a utopian dimension, perceived as striking the perfect balance between socialist beliefs and capitalist economic practices. Despite these ideological underpinnings, racist attitudes persisted, and films from this period and beyond that focus on race and ethnicity challenge and partially contradict the officially sanctioned perception of harmony and social equality. Numerous examples from Sweden, such as Gustaf Edgren's Trötte Teodor/‘Tired Theodore' (1931) and Per-Axel Branner's Pettersson and Bendel (1933), depict the Jews in overtly racist ways (see Wright 1998: 1 - 68). Branner's film was even picked up in Nazi Germany and 'led directly to acts of violence against the Jews' (Wright 2011: 270). Although it reached a limited audience, another particularly virulent example is George Willoughby's Panik (1939) where the suicide of business magnate Torsten Kreuger, a historical figure, becomes part of an international Jewish plot. ${ }^{1}$ These films and others highlight the contradictory values at work in the developing welfare state, especially regarding some of the burgeoning notions of inclusion. Notable examples of cinematic racism from other Nordic countries during the same pivotal period include Kфbenhavn, Kalundborg og-? /'Copenhagen, Kalundborg and-?' (Brandstrup and Madsen, 1934), a Danish film known for its use of blackface, and renowned Norwegian director Tancred Ibsen's Fant/'Tramp' (1937), in which the young female protagonist on the run from her abusive uncle is held captive and raped by a gypsy man.

During the turbulent war years, as film production in Norway and Denmark suffered under Nazi occupation, the gypsy theme continued to captivate Finnish audiences, for instance in Kulkurin valssi/‘The Vagabond's Waltz' (Särkkä, 1941), whose exotic circus-dwelling Roma doubtless offered an escape from the painful reality of the ongoing war. Negative Traveller representations are also evident on Swedish screens, where "the "darkie" Traveller stereotype -- the man a rapist, the woman a vamp and both amoral thieves, parasites, violent brutes and murderers - is a strong presence in the prolific film production of the 1940s' (Tapper 2014: 47). In the 1950s, the perceived otherworldly abilities of the Sami are exploited in full in the early Finnish horror film Valkoinen peura/The White Reindeer (Blomberg, 1952), where a young woman is turned into a bloodthirsty shapeshifting reindeer by a Sami shaman.

Before the countercultural movement of the 1960s, where attitudes were more openly sympathetic towards minority groups even in mainstream cinema, Astrid Henning-Jensen's 
Academy Award-nominated Paw/A Boy of Two Worlds (1959) offered a view strikingly different from the largely negative representations from the first half of the twentieth century. It was one of the first ethnically-orientated films to sympathetically feature the perspective of an immigrant, a young West Indian boy who is forced to live in Denmark after losing his parents. In contrast to the previous examples, Henning-Jensen introduces a self-reflexive dimension by referencing Denmark's colonial past.

\section{Multicultural interventions and emergent first generation directors}

As with the development of the Nordic film industries, laws governing immigration vary significantly among these five nations (Kivisto and Wahlbeck 2013). In the 1960s and '70s, however, following the breakup of political regimes in parts of the Middle East and Europe, the Nordic countries experienced their first wave of mass immigration, and new legislation was introduced aimed at policing these new populations. The guest worker programmes in Sweden and Denmark also contributed to the flow of people moving into the region. This scheme imported foreign labour to support booming economic growth, with the expectation that this workforce would eventually return to their respective homelands. Many nevertheless permanently resettled in the Nordic region and moved their families in from abroad (JaffeWalter 2016: 31-32). This prompted a drive to reunify divided families and integrate them into society. As mainstream politics adapted to accommodate the cultural changes brought about by these new populations, the concept of multiculturalism became a key part of the liberal agenda (Wickström 2013: 132-135). Simultaneously, attitudes towards cinema as a medium also began to change. Politicians and countercultural activists alike came to understand film as a significant political and ideological tool. Although immigration and ethnic diversity did not became a recurrent cinematic motif until the 1990s, there were several examples in the '70s and '80s where new and emerging cultures became the focus of on-screen representation.

On the back of this rhetoric, examples like Johan Bergenstråhle's Jag heter Stelios/ Foreigners (1972) emerged, following the trials and tribulations of a group of Greeks in Sweden. These were broadly sympathetic portrayals of newcomers struggling against state bureaucracy, harsh working conditions and discrimination to find their place in an alien environment. The first non-Nordic filmmakers also made their debuts in the 1970s. Yugoslavian immigrant Voja Miladinovic's fittingly titled debut Gastearbejdere/Guest Workers premiered in Denmark in 1974 and Turkish-born Muammer Özer's Splittring/Fragmentation in Sweden in 1984. There was a growing consensus that immigrants 
should tell their own stories and Miladinovic and Özer's contributions as first generation filmmakers echoed this standpoint.

Until recently, support for anti-immigrant parties has been patchy across the Nordic region. However, during the '70s, populist, radical right movements emerged and quickly evolved in the '80s to include a staunch anti-immigrant approach, mobilizing against perceived threats to the cohesive values of the welfare states (Arter 1999: 115-119). Despite these political developments, the 1980s were a largely prosperous decade. The Nordic countries had embraced free-market neoliberalism and political attitudes towards the welfare states began to favour individualism over the traditional collectivist position. Several Nordic films overtly questioned this ideology by drawing attention to the politics of immigration and rifts in the social fabric. Swedish director Suzanne Osten, who according to Tytti Soila 'has taken a militant attitude in the treatment of the immigrant issue' (1998: 219), released Tala! Det är så mörkt/ Speak Up! It's So Dark (1993), exploring the interaction between a volatile neo-Nazi skinhead and his Jewish psychotherapist. Another cross-cultural connection is depicted in the Danish 17 op/17 Up (Wielopolska, 1989), where a white working-class teenager from a racist family befriends her solitary Turkish neighbour. The poverty of their surroundings reinforces their unlikely friendship, and in addition to providing an alternative commentary on race relations the film explicitly depicts social dysfunction in the Danish welfare state. Both examples represent a break with previous narrative trends by attempting to bridge gaps between opposing cultures.

\section{The rise of the 'ethnic' gangster film}

Following the period of relative prosperity in the '80s, a debilitating recession hit the Nordic economies in the 1990s. In discussing the position of immigrants in Finland during this tumultuous decade, Matti Similä draws a direct correlation between economic instability, unemployment and escalating racial tensions (2003), an observation that applies to the other Nordic countries as well. These links are also evident on-screen. During the 1990s, racial and ethnic conflicts are largely visible in an emerging sub-genre fixated on gangsters. Here we see immigration cinema explicitly contesting the egalitarian narratives of the '60s and '70s. These films are typically raw and violent with a documentary-like aesthetic, for instance in 30:e november/Cry (Fridell, 1995), Schpaaa/Bunch of Five (Poppe, 1998) and Nattbuss 807/Night Bus 807 (Flamholc, 1997). In these narratives, the multiculturalist mindset of the late 1970s has utterly failed to materialize. Although these films and others focus on welfare poverty, dysfunctional families and racial alienation, many are poorly executed and rely on 
ethnic stereotypes such as the brutal Eastern European criminal or underhanded Arab. In their critique of multiculturalism, they create their own divisions by pitting ethnic groups against one another. In other variations of the Nordic ethnic gangster film, cultural differences are played for laughs. Lasse Spang Olsen's 'comedy' I Kina spiser de hunde/In China They Eat Dogs (1999) is one such example where the amusement is drawn from treating an Eastern European member of a Danish gang like a subordinate. Much like the social realist gangster films of the period, Olsen's contribution reverses the perspectives explored by Wielopolska and Osten, where the focus was on attempted crossovers between different cultures and contrasting political ideologies. As they rarely move beyond depictions of ethnic division, their challenges to societal order play into dominant hegemonic narratives of Otherness by reinforcing the us vs. them mentality.

Despite these issues, some filmmakers have used this tribalism to explore more critical self-representations. This more nuanced approach can be found in Gå med fred, Jamil/Go With Peace, Jamil (2008), directed by Danish-Palestinian actor and filmmaker Omar Shargawi. Set in a suburb of Copenhagen in the present day, Shargawi's film is shot entirely from the perspective of Denmark's Arab community and only a few lines of Danish are spoken. In this brutal revenge thriller, factions of the Sunni and Shia communities go head-tohead when young Danish-Palestinian immigrant Jamil (Dar Salim) goes after the man who murdered his mother decades earlier. Religious fervour also fuels the division between these insular communities. Although the film deals with issues seemingly alien to a largely secular Denmark, Shargawi uses this distant example to discuss the concept of forgiveness and the universal human desire for vengeance. The film also shows us division and strife within Muslim communities, a minority frequently misrepresented as a homogeneous society. Shargawi encountered criticism from some reviewers for failing to address issues closer to both Denmark and Europe. ${ }^{2}$ The film's complex mode underlines my argument that while immigration politics has grown more sophisticated throughout the 2000s, many problems remain, not least concerning the challenges facing directors off-screen.

\section{Different approaches to immigrant politics in contemporary Nordic cinema}

Representations of race and ethnicity have developed across many genres. Finnish auteur Aki Kaurismäki has a longstanding reputation for framing social exclusion in his heavily stylized portraits of contemporary Western societies. Le Harve (2011) is a modern political fairy-tale about a child refugee from Africa who is rescued by an impoverished French author. This Kaurismäkian take on the global refugee crisis also targets the 'fortress Europe' attitude 
towards migrants, many of whom are fleeing conflict and political collapse in their homelands. Similar ideas are expressed in another context where overt references to race and ethnicity are rare, as in the case of Icelandic cinema. Róbert Ingi Douglas's romantic comedy Maður eins og ég/A Man Like Me (2002), about the fraught relationship between a lonely Icelandic man and a Chinese waitress, makes inroads into the subject by thematizing an intercultural encounter. Henrik Ruben Genz's Kinamand/Chinaman (2005) explores related themes in a Danish context, depicting an arranged marriage between a Chinese immigrant and a Danish divorcee.

Other so-called comedies like Ilkka Vanne's Finnish Vieraalla maalla/Land of Love (2003) are less successful in their attempts at capturing the immigrant experience. The film follows a student researching ethnic minorities and how they interact and assimilate with the local Helsinki population. Bizarrely, his approach is to study these minorities more closely by disguising himself as one of them. The blackface caricature that results is employed without irony and the one-dimensional characters fail to offer any insight into multicultural Finland. By contrast, Lukas Moodysson's Lilja 4-ever (2002) explores transnational mobility through a harrowing semi-biographical tale of sex trafficking in contemporary Sweden. Although sympathetic in his approach, Moodysson leans heavily on Swedish exceptionalism, that is, the notion that Sweden's political motivations and ethical approaches, particularly towards global problems, are superior to others' (Volquardsen 2015: 33-34).

Race and ethnicity also feature in a new wave of documentaries. Two notable examples, Jag är fan en Panter/I'm a Fucking Panther (Jerez, Palmestål and Rundberg, 2014) and Velkommen til Norge/Welcome to Norway (Bertheussen, 2008) approach the subject in markedly different ways. Bertheussen's film, not to be confused with Rune Denstad Langlo's 2016 comedy-drama Welcome to Norway!, follows a group of refugee children from the Congo as they resettle in Stjørdalen and echoes the egalitarian trend of cinema in the 1970s. I'm a Fucking Panther is about an ethnically diverse group of young political activists fighting prejudice and far-right politics, thus reinforcing the political agency of an emerging generation. In addition, the film's alternative funding channel as a crowdfunded production sets it apart from its industry-produced counterparts and challenges some of the hegemonic restraints of the dominant production culture where narratives often focus on paternalistic representations.

\section{Crisis in the Nordic nations: Challenging popular images}


Ethnic minorities were subject to derogatory treatment in the first half of the twentieth century. Their economic significance in post-war Scandinavia instigated a drive towards multicultural inclusion, but by the 1990s, these promises had failed to materialize. In the new wave of ethnic gangster films, the welfare states are in crisis and filmmakers broaden the scope of their critique by showing the Nordic welfare dream to be just that. More recent examples, however, have seen ethnic conflicts redefined as universal human struggles. Some skillfully manage this without neglecting racial politics. Films like Gabriella Pichler's Äta sova dö/Eat, Sleep, Die (2012) draw on economic hardship and painful working-class exclusion where race and ethnicity are woven into these subjects. Here, unemployment, economic inequality and the exploitation of rural workforces are experienced through the eyes of the young female Muslim protagonist.

Other filmmakers, such as Sweden's Ruben Östlund, continue to challenge and provoke audiences in ways that differ from more conventional egalitarian narratives. His 2011 docudrama Play, based on a series of robberies in the Swedish city of Göteborg, forced Swedish spectators out of their comfort zone by casting only black adolescents as the antagonists. He also targets misguided liberal attitudes and general complacency amongst the Swedish public, sparking a fierce debate in the same newspapers responsible for constructing populist immigrant narratives. Although critical of Östlund's perceived white, middle-class target audience, Elisabeth Stubberud and Priscilla Ringrose use Play's imagery to discuss how language as a discourse has failed to address problems with race in contemporary Sweden (2014). Instead, Play's imagery and backdrop reinforce clear boundaries between people and the establishment. Like Pichler, Östlund uses these boundaries to critique the destructive influence of the Nordic capitalist mentality. In doing so, both directors challenge us to confront the causes of these racial divisions instead of being content with relying on an 'easy' multiculturalist acceptance of the status quo.

\section{Conclusion}

First and second generation immigrant directors still face many hurdles, not least in the Nordic film industries where minorities are underrepresented at all levels of production. The criticism directed at Shargawi reinforces the sense that embedded cultural and political perceptions shape the availability of roles and positions for artists who are, in one way or another, perceived as ethnically divergent. There is a culture of expectation facing minority filmmakers. They are duty-bound by a perception of their cultural Otherness to address the most relevant and pressing political subjects, even if these are only vaguely linked to a 
director's ethnic background. This damaging assumption reduces the role of minority directors to ambassadors or sanctioned representatives for whole communities of people who are as complex and divided as any other population.

The film cultures of the five small Nordic nations reflect the complexity of their political and economic landscapes. Like the rest of Europe, these countries face pressing questions about the treatment of refugees and asylum seekers. Alongside these political struggles, cinema will continue to echo and challenge popular representations. At different stages of Nordic film history, filmmakers have pushed against the limitations of cultural attitudes and accepted social norms. As more nuanced understandings of racial conflict have emerged, the Nordic film cultures clearly have much to offer on these politically and culturally divisive subjects.

\section{References}

Arter, David (1999), Scandinavian Politics Today, Manchester: Manchester University Press.

Ballesteros, Isolina (2015), Immigration Cinema in the New Europe, Bristol: Intellect.

Gustafsson, Tommy (2014), Masculinity in the Golden Age of Swedish Cinema: A Cultural Analysis of 1920s Films, North Carolina: McFarland and Company.

Horsti, Karina (2008), 'Overview of Nordic Media Research on Immigration and Ethnic Relations: From Text Analysis to the Study of Production, Use and Reception', Nordicom Review 29: 2, pp. 278-93.

Jørholt, Eva (2007), 'Perkere og andet godtfolk: De fremmede i dansk film', Kosmorama 240, pp. 7-32.

Kananen, Johannes (2014), The Nordic Welfare State in Three Eras: From Emancipation to Discipline, Farnham: Ashgate Publishing.

Kivisto, Peter and Wahlbeck, Östen (2013), Debating Multiculturalism in the Nordic Welfare States, Basingstoke: Palgrave Macmillan.

Loftsdóttir, Kristín and Jensen, Lars (2014), Crisis in the Nordic Nations and Beyond: At the Intersection of Environment, Finance and Multiculturalism, London: Routledge.

Madsen, Christian Erin (2008), 'Blodhævn-fulgt af nagende tvivl', http://www.b.dk/kultur/blodhaevn-fulgt-af-nagende-tvivl. Accessed 17 October 2016.

Nordlund, Sven (1999), 'The War is Over- Now You Can Go Home!' Jewish Refugees and the Swedish Labour Market in the Shadow of the Holocaust', Holocaust Studies: A Journal of Culture and History 9, pp. 171-198. 
Redvall, Eva Novrup (2010), 'Omar Shargawi’, in Mette Hjort, Eva Jørholt and Eva Novrup Redvall (eds), Danish Directors 2: Dialogues on the New Danish Fiction Cinema, Bristol: Intellect, pp.233-247.

Similä, Matti (2003), 'Immigrants and Minorities in Finland: Problems and Challenges', in David Turton and Julia González (eds), Immigration in Europe: Issues, Policies and Case Studies, Bilbao: University of Deusto, pp. 97-113.

Soila, Tytti (1998), 'Sweden', in Astrid Söderbergh, Gunnar Iversen and Tytti Soila (eds), Nordic National Cinemas, London: Routledge, pp. 135-221.

Stubberud, Elisabeth and Ringrose, Pricilla (2014), 'Speaking Images, Race-less Words: Play and the Absence of Race in Contemporary Scandinavia', Journal of Scandinavian Cinema 4: 1, pp. 61-76.

Tapper, Michael (2014), Swedish Cops: From Sjöwall and Wahlöö to Stieg Larsson, Bristol: Intellect.

Triandafyllidou, Anna and Gropas, Ruby (2007), European Immigration: A Sourcebook, Farnham: Ashgate Publishing.

Volqarsden, Ebbe (2014), 'Scandinavia and "The land of UnSwedish Freedom" : Jonathan Franzen, Susanne Bier and the Self-conceptions of Exceptionalism in Crisis', in Kristín Loftsdóttir and Lars Jensen (eds), Crisis in the Nordic Nations and Beyond: At the Intersection of Environment, Finance and Multiculturalism, London: Routledge, pp. 3151.

Walter, Reva Jaffe (2016), Coercive Concern: Nationalism, Liberalism, and the Schooling of Muslim Youth, Stanford: Stanford University Press.

Westerståhl Stenport, Anna (2014), 'Lilya 4-ever: Post-Soviet Neoliberal Angels and Nordic Intellectual Secularism', Scandinavica 53:1, pp. 37-58.

Wickström, Mats (2013), 'A Conceptual Change in Postwar Sweden: The Marginalization of Assimilation and the Introduction of Integration', in Peter and Östen Wahlbeck (eds), Debating Multiculturalism in the Nordic Welfare States, Basingstoke: Palgrave Macmillan, pp. 110-39.

Wodak, Ruth (2015), The Politics of Fear: What Right-Wing Populist Discourses Mean, London: Sage.

Wright, Rochelle (1998), The Visible Wall: Jews and Other Ethnic Outsiders in Swedish Film, Carbondale: Southern Illinois University Press. 
(2005), 'Immigrant Film in Sweden at the Millennium', in Andrew Nestingen and

Trevor Elkington (eds), Transnational Cinema in a Global North: Nordic Cinema in

Transition, Detroit: Wayne State University Press, pp. 55-73.

(2011), 'Swedish Film and Germany, 1933-45', in Roel Vande Winkel and David

Welch (eds), Cinema and the Swastika: The International Expansion of Third Reich

Cinema, Basingstoke: Palgrave Macmillan, pp. 265-75.

\section{Film References}

Bergenstråhle, Johan (1972), Jag heter Stelios, Sweden.

Bertheussen, Mona Friis (2008), Velkommen til Norge, Norway.

Blomberg, Erik (1952), Valkoinen peura, Finland.

Brandstrup, Ludvig and Madsen, Holger (1934), Kфbenhavn, Kalundborg og-?, Denmark.

Branner, Per-Axel (1933), Pettersson and Bendel, Sweden.

Denstad, Rune Langlo (2016), Welcome to Norway!, Norway.

Douglas, Róbert Ingi (2002), Maður eins og ég, Iceland.

Edgren, Gustaf (1931), Trötte Teodor, Sweden.

Flamholc, David (1997), Nattbuss 807, Sweden.

Fridell, Daniel (1995), 30:e november, Sweden.

Genz, Henrik Ruben (2005), Kinamand, Denmark.

Jensen, Astrid Henning (1959), Paw, Denmark.

Jerez, Jennifer, Palmestål, Leo and Rundberg, Anders (2014), Jag är fan en Panter, Sweden.

Kaurismäki, Aki (2011), Le Harve, Finland.

Miladinovic, Voja (1974), Gastearbejdere, Denmark.

Moodysson, Lukas (2002), Lilja 4-ever, Sweden.

Olsen, Lasse Spang (1999), I Kina spiser de hunde, Denmark.

Osten, Suzanne (1993), Tala! Det är så mörkt, Sweden.

Östlund, Ruben (2011), Play, Sweden.

Özer, Muammer (1984), Splittring, Sweden.

Pichler, Gabriella (2012), Äta sova dö, Sweden.

Poppe, Erik (1998), Schpaaa, Norway.

Shargawi, Omar (2008), Gå med fred, Jamil, Denmark.

Särkkä, Toivo (1941), Kulkurin valssi, Finland. 
Tancred, Ibsen (1937), Fant, Norway.

Vaala, Valentin (1929), Mustat silmät, Finland.

_ (1929), Mustalaishurmaaja, Finland.

Vanne, Ilkka (2003), Vieraalla maalla, Finland.

Wielopolska, Brita (1989), 17 op, Denmark.

Willoughby, George (1939), Panik, Sweden.

${ }^{1}$ According to Sven Nordlund, racism against the Jews was also driven by Sweden's economic links with Germany during the '30s, which led to the 'Aryanisation' of Swedish trade relations and the exclusion of Jewish businesses (Nordlund 1999).

${ }^{2}$ According to Shargawi, those issues included the 2005 Jyllands-Posten Prophet Muhammed cartoons controversy that had provoked a global backlash and damaged Denmark's international relations with the Middle East (Redvall 2010: 245-6). 